\title{
TNFAIP3 alleviates pain in lumbar disc herniation rats by inhibiting the NF-кB pathway
}

\author{
Zhaohui Xie ${ }^{1}$, Jixiang Chen ${ }^{1}$, Zhengjun Xiao ${ }^{1}$, Yuqin $\mathrm{Li}^{1}$, Tao Yuan ${ }^{1}$, Yandong $\mathrm{Li}^{2}$ \\ ${ }^{1}$ Department of Pain, The First Hospital of Lanzhou University, Lanzhou, China; ${ }^{2}$ Department of Surgery, Shuguang Hospital, Zhangye, China \\ Contributions: (I) Conception and design: Z Xie, Y Li; (II) Administrative support: J Chen; (III) Provision of study materials or patients: Z Xie; \\ (IV) Collection and assembly of data: Z Xiao; (V) Data analysis and interpretation: Y Li, T Yuan; (VI) Manuscript writing: All authors; (VII) Final \\ approval of manuscript: All authors. \\ Correspondence to: Yandong Li. Department of Surgery, Shuguang Hospital, Zhangye, China. Email: 3082672708@qq.com.
}

\begin{abstract}
Background: It's been reported that the tumor necrosis factor alpha inducible protein 3 (TNFAIP3) gene played an important role in the pathogenesis of autoimmune and chronic inflammation diseases. Moreover, in degenerative diseases of the lumbar spine the nuclear factor- $\kappa \mathrm{B}(\mathrm{NF}-\kappa \mathrm{B})$ pathway is significantly activated. This study aimed to explore the role of the tumor necrosis protein-induced zinc finger protein A20 (A20) protein in degenerative diseases of the lumbar spine on the NF- $\kappa$ Bp65 pathway.

Methods: A total of 96 rats were randomly divided into 4 groups. Lumbar disc herniation (DH) was set as a sham operation group (Sham group), DH + A20 group and DH + control group (Control group); measured changes in rat paw withdrawal threshold (PWT) and paw withdrawal latency (PWL); detected the proportion of apoptotic cells in a single nucleus pulposus cell suspension, analyzed the correlation between tumor necrosis factor- $\alpha$ (TNF- $\alpha$ ) content and pain in DH rats, and the expression changes of NF- $\kappa$ B pathway in nucleus pulposus tissue.
\end{abstract}

Results: compared with the DH + Control group, the PWT and PWL of the DH + A20 group increased significantly $(\mathrm{P}<0.05)$; apoptosis in the $\mathrm{DH}+\mathrm{A} 20$ group was significantly reduced $(\mathrm{P}<0.01)$; the nucleus pulposus tissue and serum levels of TNF- $\alpha$ and interleukin-6 (IL-6) in the DH + A20 rat group were significantly lower than those in the $\mathrm{DH}+$ Control group $(\mathrm{P}<0.05)$; the protein expression of rats in the $\mathrm{DH}$ + A20 group (p-p65) was significantly lower than that in the $\mathrm{DH}+$ Control group $(\mathrm{P}<0.05)$.

Conclusions: The pain of lumbar disc herniation rats is related to TNF- $\alpha$, and overexpression of A20 protein can reduce the pain of lumbar disc herniation by inhibiting the NF- $\mathrm{B}$ pathway.

Keywords: Lumbar disc herniation (lumbar DH); tumor necrosis factor- $\alpha$ (TNF- $\alpha$ ); interleukin-6 (IL-6); tumor necrosis factor alpha inducible protein 3 (TNFAIP3)

Submitted Oct 08, 2021. Accepted for publication Jan 14, 2022.

doi: $10.21037 / \mathrm{atm}-21-6499$

View this article at: https://dx.doi.org/10.21037/atm-21-6499

\section{Introduction}

Back pain brings serious challenges to modern people's life and health, $60-80 \%$ of people have experienced it at least once in their lives (1). The most significant clinical feature of lumbar disc herniation is back pain, and with the change of living habits and sedentary work hours, DH is affecting more and more young patients. Adults aged
30-50 have the highest probability to suffer from disc herniation $(\mathrm{DH})$, and the ratio of male to female is 2:1 (2). DH usually presents as a recurrent symptom of lower back pain and sciatica, in which mechanical compression and inflammation caused by the immune system are the main pathological changes $(3,4)$. In the past, the mainly clinical treatment of pain caused by lumbar disc herniation is conservative treatment methods. The methods include 
oral non-steroidal anti-inflammatory drugs, sacral hiatus epidural injection, traction, acupuncture and massage, etc., which has achieved certain effects. However, the underlying mechanism of low back pain and sciatica are still unknown. Therefore, there is no effective way to treat the main symptoms. The treatment of symptomatic DH includes conservative treatment, minimally invasive surgery and traditional surgery (5). Facts have proved that both surgical and non-surgical treatments can effectively treat symptomatic DH. However, the incidence of surgeryrelated complications is $15-30 \%$, and the postoperative recurrence rate is $2-25 \%(6,7)$. Conservative methods such as physical therapy are often used clinically as the first choice for the treatment of $\mathrm{DH}$, and are usually used for the treatment of pain and recovery of function and neurological deficits (8).

A20 protein encoded by tumor necrosis factor alpha inducible protein 3 (TNFAIP3) gene which is necessary for the development and functional performance of dendritic cells, B cells, T cells, and macrophages. It's reported that A20 protein is an important negative feedback regulator

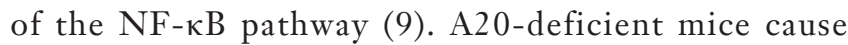
multiple organ inflammation and early death of cachexia due to excessive TNF-induced NF- $\mathrm{KB}$ activation $(10,11)$. TNFAIP 3 gene mutations are related to the pathogenesis of chronic inflammation and autoimmune diseases (12-16) and B-cell lymphoma $(17,18)$. NF- $\mathrm{kBp} 65$ is the main factor that plays a role in the NF- $\mathrm{kB}$ pathway. It mainly promotes the release of inflammatory factors, is often activated in the inflammatory response, and increases the chronic inflammatory damage of the intestinal mucosal tissue (19). The activation of NF- $\mathrm{KBp} 65$ promotes the inflammation and hyperalgesia of adjuvant arthritis in rats (20). The NF$\kappa \mathrm{B}$ pathway is activated when the lumbar spine undergoes degenerative changes. Therefore, the inhibiting the activation of NF- $\mathrm{KB}$ pathway may be a potential treatment method to alleviate the pain of lumbar disc herniation. Previous studies have found that the nucleus pulpoeus has the properties of biochemical inflammation and immunology, which can induce nerve root pain. TNFAIP3 can reduce the onset of inflammatory pain. Besides, the NF- $\kappa \mathrm{B}$ pathway played an important role in the occurrence and development of pain associated with lumbar disc herniation. However, whether TNFAIP3 can regulate NFкBp65 pathway to reduce the occurrence of pain associated with lumbar disc herniation remains unclear. The purpose of this study is to explore the effect of A20 protein induced by tumor necrosis protein on the NF- $\mathrm{NBp} 65$ pathway.
We present the following article in accordance with the ARRIVE reporting checklist (available at https://atm. amegroups.com/article/view/10.21037/atm-21-6499/rc).

\section{Methods}

\section{Experimental materials}

$\mathrm{SD}$ rats were purchased from the laboratory animal center of our hospital, IL-6 and TNF- $\alpha$ ELISA kit (BlueGene, Shanghai, China), tumor necrosis factor $\alpha$ inducible protein 3 stable expression plasmid and empty plasmid (Jikai Gene, Shanghai, China). TRIzol (Anoon Biotechnology Co., Ltd., Beijing, China), Primary antibody (Abcam, USA), SYBR Green Buffer (Roche, USA), BCA (Pulilai, Beijing, China). Chloral hydrate (Qingdao Yulong Seaweed Co., Ltd., Shandong, China), isothiocyanate (Xi'an Baiying Biological Technology Co., Ltd., Shaanxi, China), flow cytometer (Guangzhou Jiyuan Biotechnology Co., Ltd., Guangzhou, China), PrimeScript ${ }^{\mathrm{TM}}$ RT kit (Beijing Mai Ruibo Biotechnology Co., Ltd., Beijing, China).

\section{Research objects}

For SD rats, the animal model of lumbar disc herniation (DH) and the sham operation group (Sham) were constructed according to the following methods, intermediated $\mathrm{DH}$ rats with the stable expression plasmid $(\mathrm{DH}+\mathrm{A} 20)$ and empty plasmid (DH + Control) of tumor necrosis factor alpha-induced protein 3 , and after 14 days of feeding, the peripheral blood of the rats was collected, and the nucleus pulposus tissue was dissected and separated perform follow-up experiments. This study was approved by the ethics committee of the First Hospital of Lanzhou University [approval No. (2020) No. 9-2], in compliance with The Principles of Human Experimental Technique, which is a national guideline for the care and use of animals to minimize the suffering of experimental animals.

\section{Experimental method}

\section{Construction of experimental animal models}

Before the operation, the rat's back and abdomen hair were shaved, and the rat was anesthetized by intraperitoneal injection of $10 \%$ chloral hydrate at a dose of $350 \mathrm{mg} / \mathrm{kg}$. Making an incision on the left side of the body, observing the principle of septicity, and make an incision length of 3-3.5 cm. The nucleus pulposus (NP) was harvested 
Table 1 Primer sequence

\begin{tabular}{ll}
\hline Gene & Primer sequence $\left(5^{\prime} \rightarrow 3^{\prime}\right)$ \\
\hline TNF- $\alpha$ & F: CGGTGCCTATGTCTCAGCCTCTTCT \\
& R: TGGTGGTTTGTAGTGTGAGGGTCTG \\
IL-6 & F: TGGAGTCACAGAAGGAGTGGCTAAGG \\
& R: GCATAACGCACTAGGTTTGCCGAGTA \\
$\beta$-actin & F: GAAGATCAAGATCATTGCTCCT \\
& R: TACTCCTGCTTGCTGATCCA
\end{tabular}

between the second and third caudal discs of the rat tailbone. After exposing the ventral posterior wall, cutting the L5 and L6 nerve roots. Placing the NPs on top of the left L5 and L6 nerve roots. Then, washing the wound with saline and bandaging it with sterile gauze. Intervertebral discs were removed without NP transplantation as a sham operation group. Four days after the operation, DH rats were injected intrathecal with tumor necrosis factor alphainduced protein 3 stable expression plasmid and empty plasmid. The rats were fed in single cages and fasted after the operation. Penicillin was continuously administered to the animals for 3 days. After taking 10\% chloral hydrate, the rats have normal appetite without obvious signs of infection, peritonitis or death.

\section{Mechanical allodynia test}

The rats were accustomed to the test environment by placing them in the test room for 20 minutes three days before the formal test. A set of von Fress (0.41, 0.70, 1.20, 2.04, 3.63, $5.50,8.51,15.14 \mathrm{~g}$ ) was used to evaluate the mechanical pain threshold, and the method was as described above. First applying $2.04 \mathrm{~g}$ to stimulate. If the paw is not retracted, the next stronger stimulus is applied. Instead, a weaker stimulus was chosen. The stimulus was applied to the surface of the hind paw for 6-8 s each time, with an interval of 5 minutes between the two stimuli. Retreat or paw licking after stimulation is considered a positive reaction.

\section{Flow cytometric detection of changes in nucleus pulposus cell apoptosis}

Resuspending the collected nucleus pulposus cells in $100 \mu \mathrm{L}$ Annexin V conjugate buffer $\left(1 \times 10^{5}\right.$ cells), containing $5 \mu \mathrm{L}$ PI and $5 \mu \mathrm{L}$ Annexin V-fluorescein isothiocyanate. Subsequently, the FACSCalibur ${ }^{\mathrm{TM}}$ flow cytometer was used to detect cell apoptosis within 1 hour. TUNEL staining was used to detect cell apoptosis. The nucleus pulposus cells were collected and resuspended to prepare a single cell suspension, after fixation with a fixative, they were incubated at room temperature for 2 hours, and then were blocked by methanol solution. After incubating them at room temperature for 15 minutes, then adding $50 \mu \mathrm{L}$ of TUNEL reaction solution and incubating in the dark. Cell apoptosis was observed under microscope, and the apoptosis index was calculated.

\section{Reverse transcription quantitative polymerase chain reaction}

Total RNA was extracted from the nucleus pulposus tissue using TRIzol reagent, and cDNA was synthesized using PrimeScript ${ }^{\mathrm{TM}} \mathrm{RT}$ kit at $37^{\circ} \mathrm{C}$ for 15 minutes and $85^{\circ} \mathrm{C}$ for 5 seconds according to the manufacturer's protocol. Then use SYBR Premix Ex Taq II to detect the expression levels of IL-6, TNF- $\alpha$ and $\beta$-actin. The thermal cycling conditions are as follows: setting 40 cycles at $95^{\circ} \mathrm{C}$ for 3 minutes; $95^{\circ} \mathrm{C}$ for 5 seconds and $60^{\circ} \mathrm{C}$ for 30 seconds; finally, $72{ }^{\circ} \mathrm{C}$ for 30 seconds. Using $2^{-\Delta \Delta \mathrm{Ct}}$ method for comparative quantification $\beta$-actin was used as an endogenous control. The primers used in the experiment are summarized in Table 1.

\section{ELISA to detect the levels of IL- 6 and TNF- $\alpha$ in peripheral blood}

The concentration of IL-6 and TNF- $\alpha$ in the serum of DH rats was determined by the ELISA method according to the manufacturer's instructions. All operations were performed at room temperature, and all samples were measured in duplicate. Using Varioskan flash multifunctional microplate reader to detect absorbance.

\section{Thermal hyperalgesia test}

The thermal pain threshold was evaluated by a plantar test. The radiant 24A heat source under the glass floor was aimed at the surface of the rat's plantar. In each test phase, each animal was subjected to 3 withdrawal latency measurements. The hind paws were tested alternately at intervals of more than 5 minutes between consecutive tests. The three latency values of each animal were averaged as the result of each test.

\section{Statistical analysis}

All data are analyzed using SPSS. Western blotting used unpaired $t$-test, and ELISA data was analyzed by oneway analysis of variance (ANOVA). $\mathrm{P}<0.05$ was considered statistically significant. 

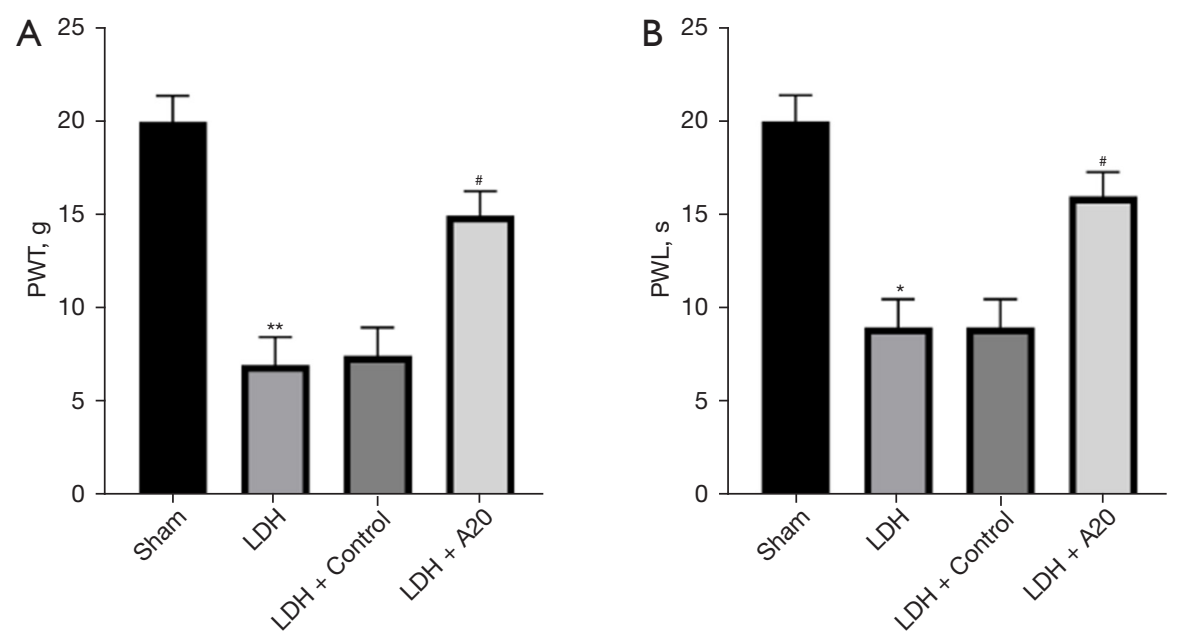

Figure 1 The effect of zinc finger protein A20 protein on withdrawal threshold PWT and withdrawal latency PWL in rats with lumbar DH. (A) PWT in DH rats was significantly lower than that in the sham operation group (Sham group) $\left({ }^{* *} \mathrm{P}<0.01\right)$, and $\mathrm{PWT}$ in $\mathrm{DH}+\mathrm{A} 20$ rats was significantly higher than that in the $\mathrm{DH}+$ control group (Control group) $\left({ }^{\#} \mathrm{P}<0.05\right)$. (B) $\mathrm{PWL}$ in $\mathrm{DH}$ rats was significantly lower than that in Sham group $\left({ }^{*} \mathrm{P}<0.05\right)$, $\mathrm{PWL}$ in $\mathrm{DH}+\mathrm{A} 20$ rats was significantly higher than $\mathrm{DH}+\mathrm{Control}\left({ }^{\#} \mathrm{P}<0.05\right)$. DH, disc herniation; PWT, paw withdrawal threshold; PWL, paw withdrawal latency.

\section{Results}

High expression of A20 protein increases withdrawal threshold paw withdrawal threshold (PWT) and withdrawal latency $\mathrm{PWL}$ in $\mathrm{DH}$ rats

Due to nucleus pulposus implantation, the 50\% PWT of the ipsilateral hind paw of DH rats was significantly reduced $(\mathrm{P}<0.01)$, while the $\mathrm{PWT}$ of the $\mathrm{DH}+\mathrm{A} 20$ group was significantly higher than that of the $\mathrm{DH}+$ Control group $(\mathrm{P}<0.05)$. For the thermal test, nucleus pulposus implantation can reduce the paw withdrawal latency (PWL) of the ipsilateral hind paw in rats 14 days after the operation $(\mathrm{P}<0.05)$, and the $\mathrm{PWL}$ threshold was significantly increased in the overexpression DH rat group $(\mathrm{P}<0.05)$. The results show that $\mathrm{DH}$ rats can produce long-lasting mechanical allodynia and thermal hyperalgesia, and high expression of A20 protein in DH rats can relieve pain and thermal hyperalgesia (Figure 1).

\section{Up-regulation of A20 protein expression inbibits the expression of IL-6 and TNF- $\alpha$ inflammatory factors}

The serum levels of IL-6 and TNF- $\alpha$ in rats in the DH group were significantly higher than those in the Sham group $(\mathrm{P}<0.05)$ on the 14th day after surgery, while the levels of IL-6 and TNF- $\alpha$ in rats in the $\mathrm{DH}+\mathrm{A} 20$ group were significantly reduced $(\mathrm{P}<0.05)$. Real-time quantitative PCR method to detect IL-6 and TNF- $\alpha$ mRNA expression is consistent with changes in peripheral blood levels. The results show that the high expression of A20 protein in DH rats can inhibit the inflammatory response in DH rats (Figure 2).

\section{The expression of TNF- $\alpha$ in $\mathrm{DH}$ rats is positively correlated with the degree of pain}

TNF- $\alpha$ plays a role in the occurrence of pain as an inflammatory factor. The correlation between VAS pain score and TNF- $\alpha$ expression in DH rats was analyzed. The results showed that the higher the expression of TNF- $\alpha$, the higher the VAS pain score of rats, and it was positively correlated $(r=0.790, \mathrm{P}<0.001)$, which indicated that the expression of TNF- $\alpha$ was positively correlated with the degree of pain in rats (Figure 3).

\section{High expression of A20 protein inbibits cell apoptosis in DH rats}

According to the fresh nucleus pulposus tissue, the nucleus pulposus cell suspension was prepared by trypsin digestion method, and the percentage of apoptotic cells was detected by flow cytometry. The data showed that compared with the Sham group, the proportion of nucleus pulposus cell 

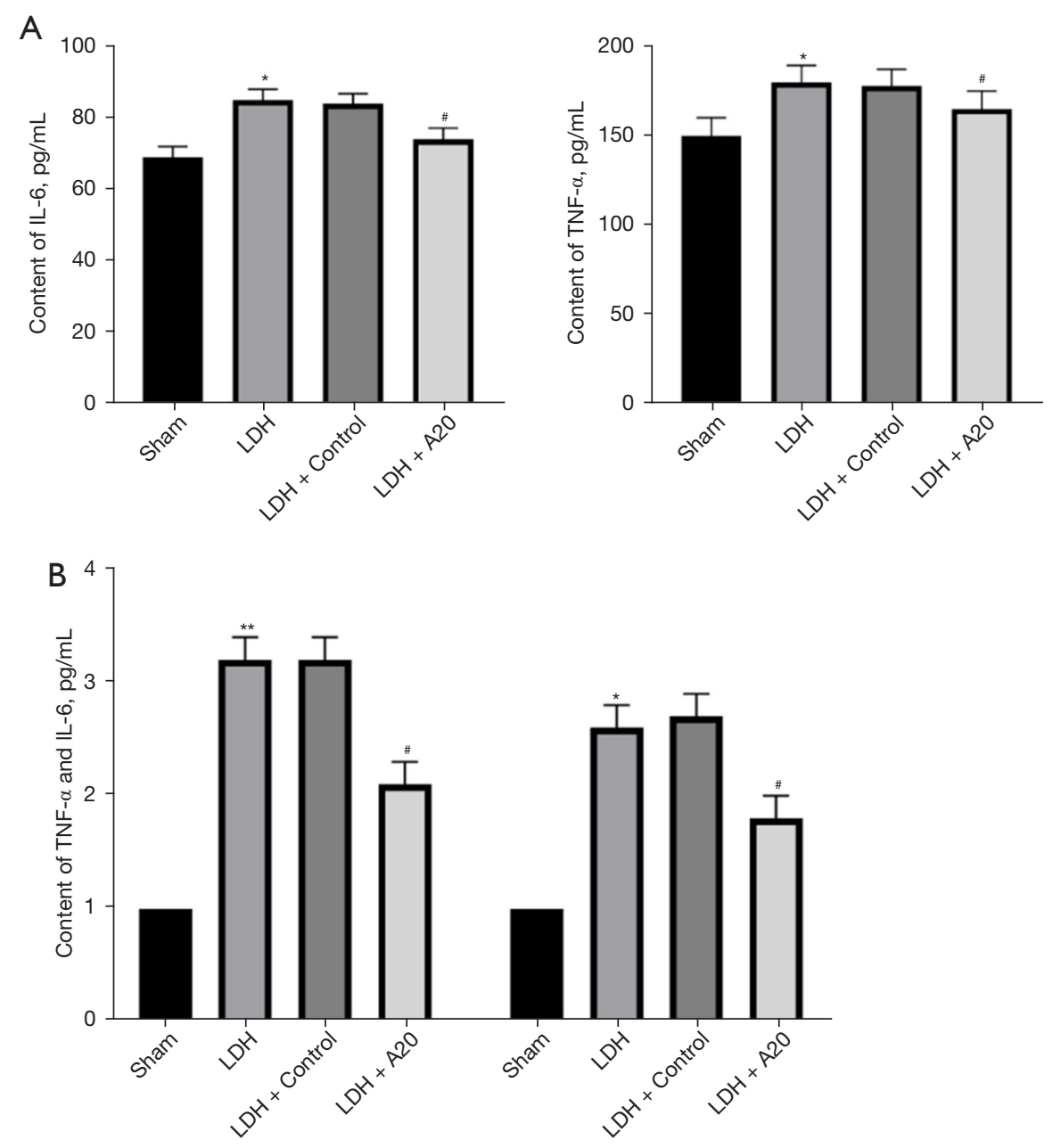

Figure 2 The effect of zinc finger protein A20 protein on the expression of inflammatory factors in rats with lumbar DH. (A) The levels of IL-6 and TNF- $\alpha$ in the peripheral blood of rats in DH, DH + Control, DH + A20 and sham operation group (Sham group) ( ${ }^{*}<0.05$, $\left.{ }^{\#} \mathrm{P}<0.05\right)$. (B) The expression of IL-6 and TNF- $\alpha$ mRNA in the nucleus pulposus in DH, DH + Control, DH + A20 and sham operation group (Sham group) $\left({ }^{* *} \mathrm{P}<0.01,{ }^{*} \mathrm{P}<0.05,{ }^{\#} \mathrm{P}<0.05\right)$. $\mathrm{DH}$, disc herniation.

apoptosis in DH rats was significantly increased $(\mathrm{P}<0.01)$; the proportion of apoptotic cells in the $\mathrm{DH}+\mathrm{A} 20$ group was significantly lower than that in the $\mathrm{DH}+$ Control group $(\mathrm{P}<0.01)$, which indicates that the nucleus pulposus cells undergo significant apoptosis after the occurrence of $\mathrm{DH}$, but up-regulating the expression of A20 protein in $\mathrm{DH}$ rats can significantly reduce the apoptosis of nucleus pulposus cells (Figure 4).

\section{High expression of A20 protein inhibits the activation of NF-кBp65 in DH rats}

Western blotting was used to detect the changes of NF- $\kappa B p 65$ pathway in the nucleus pulposus tissues of the four groups of rats. The experimental results showed that the expression of $\mathrm{p}-\mathrm{p} 65 / \mathrm{p} 65$ protein in the $\mathrm{DH}$ group was significantly higher than that in the Sham group, and the NF- $\mathrm{kBp} 65$ pathway was activated $(\mathrm{P}<0.05)$; compared with the $\mathrm{DH}+$ Control group, the expression of p-p65/p65 protein in the $\mathrm{DH}+\mathrm{A} 20$ group was significantly reduced $(\mathrm{P}<0.05)$, which indicates that the A20 protein can relieve DH pain by inhibiting the NF-кBp65 pathway (Figure 5).

\section{Discussion}

Recent research showed that pathogenesis of radiculopathy 

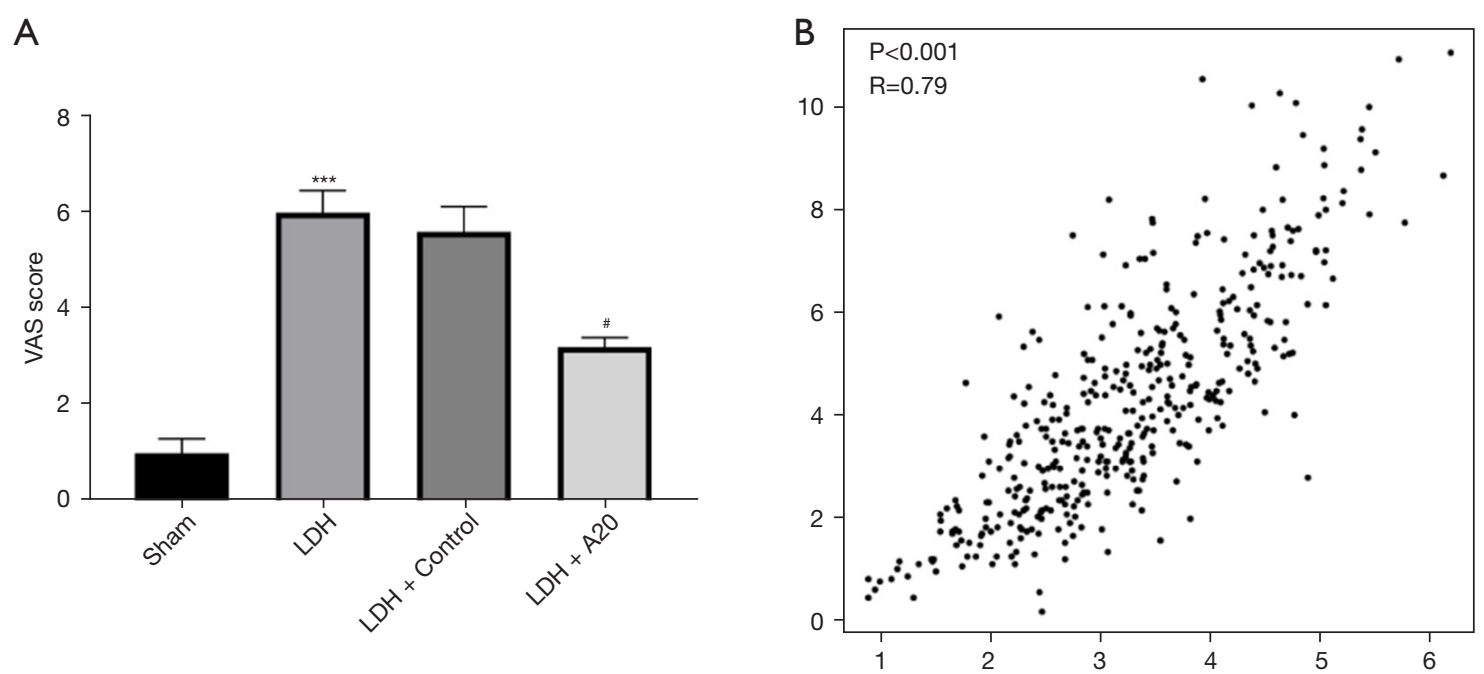

Figure 3 Correlation between pain and TNF- $\alpha$ content in rats with lumbar DH. (A) Compared with the VAS pain scores of the four groups of $\mathrm{DH}$ rats and the sham operation group (Sham group) $\left.{ }^{* * *} \mathrm{P}<0.001,{ }^{*} \mathrm{P}<0.05\right)$. (B) Correlation analysis between pain degree and $\mathrm{TNF}-\alpha$ content in DH rats. VAS, visual pain score; $\mathrm{DH}$, disc herniation.
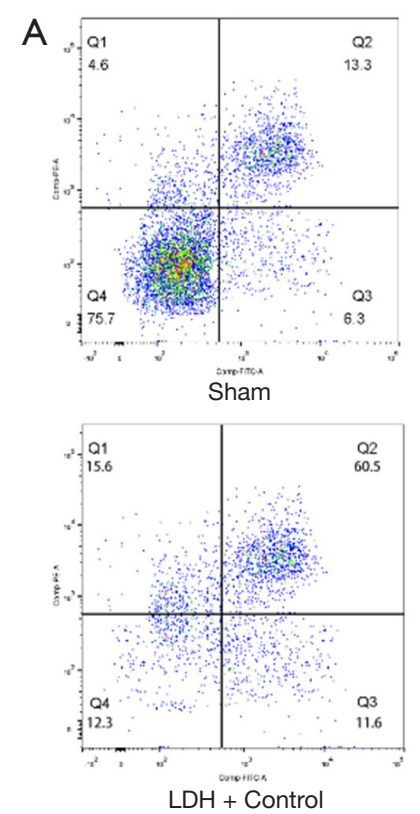
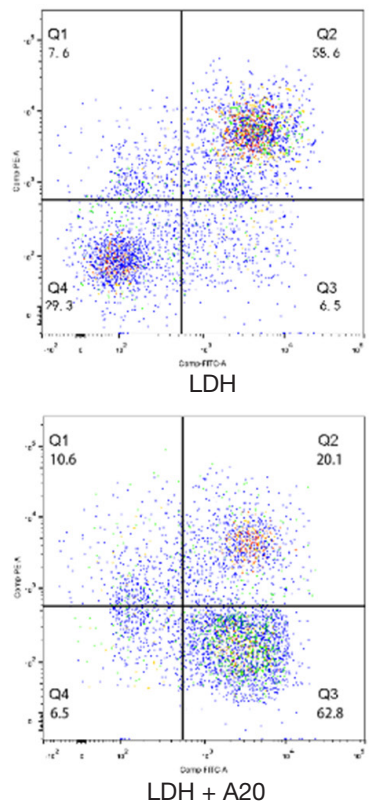

B

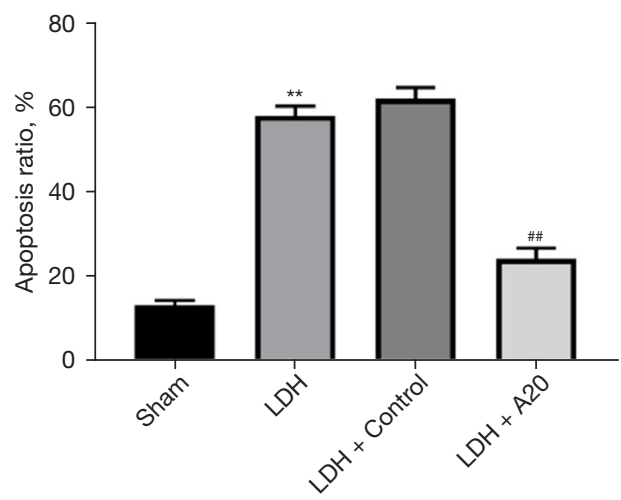

Figure 4 The effect of A20 on nucleus pulposus cell apoptosis. (A,B) Detection by flow cytometry and analysis the proportion of apoptotic cells in in DH, DH + Control, DH + A20 and sham operation group (Sham group) $\left({ }^{* *} \mathrm{P}<0.01,{ }^{* \#} \mathrm{P}<0.01\right)$.

caused by DH included mechanical compression, autoimmune and chemical stimulation of inflammatory factors (3,21). Mechanical compression is the main pathogenic factor among them. The understanding of DH in early modern medicine mainly focused on mechanical compression, and mechanical compression is considered to be the only cause of pain (22). Modern study has introduced the theory of molecular biology in the studying filed of DH. It's been reported that inflammatory factors around the lumbar spine have a significant toxic effect on the nervous 

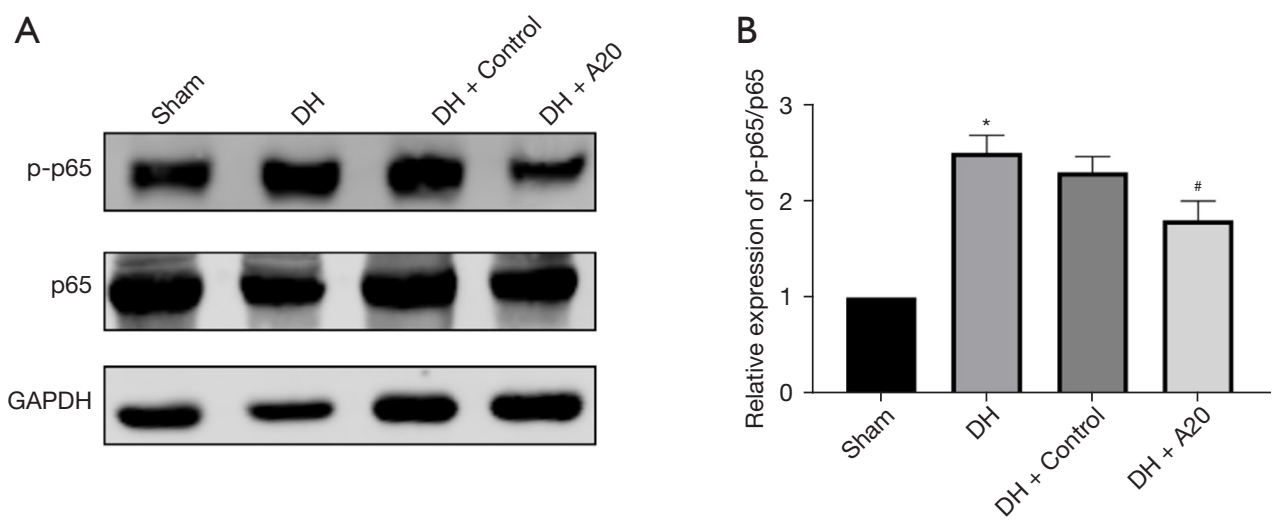

Figure 5 The effect $\mathrm{A} 20$ protein on nuclear factor- $\kappa \mathrm{B}(\mathrm{NF}-\kappa \mathrm{B})$ p65 pathway (A: the Western blot result, B: for quantitative analysis) $\left({ }^{*} \mathrm{P}<0.05\right.$, $\left.{ }^{\#} \mathrm{P}<0.05\right)$.

system, and can stimulate nerves and produce pain, which leads to DH nerve root pain. The compression of the dural sac or nerve root by nucleus pulposus may induce aseptic inflammatory reaction around the nerve root, resulting in local inflammatory edema, which may be the direct cause of sciatica (23). Our research shows that mechanical compression is not the only cause of DH waist and leg pain, and the role of inflammatory factors in pain has attracted our attention. In the past, the clinical treatment of the pain related to lumbar disc herniation is mainly combining conservative treatment or combined with surgery according to the relevant mechanism, which has achieved certain effects. However, some patients still have chronic pain for a long time after the treatment. Therefore, it is of great importance to find ways and related mechanisms to relieve the pain related to lumbar disc herniation.

Many inflammatory factors caused the occurrence and development of chronic neuropathic pain. TNF- $\alpha$ released by macrophages have a strong analgesic effect. TNF- $\alpha$ lead to root pain which can also destroy cells and lead to the production of plenty of inflammatory factors, such as IL-1, IL-6 and cyclooxygenase 2 . TNF- $\alpha$ can directly collect and regulate neutrophils and eosinophils, disrupting cellular metabolism and immune response, affecting cell proliferation and differentiation, and then producing cytotoxicity and neurotoxicity (1). IL-6 secreted by monocytes/macrophages and $\mathrm{B}$ and $\mathrm{T}$ lymphocytes is another important inflammatory factor. It is an acutephase response protein which have an effect to induce acute inflammation, promote and regulate the inflammatory response in cell proliferation and differentiation $(5,24)$. Our experimental data showed that compared with $\mathrm{DH}$ rats, the
TNF- $\alpha$ and IL- 6 content and the TNF- $\alpha$ and IL- 6 mRNA expression levels in the $\mathrm{DH}+\mathrm{A} 20$ group were significantly reduced. The expression change of inflammatory factors is consistent with the change trend of rat hind PWT, and the analysis of TNF- $\alpha$ expression level is positively correlated with pain VAS score. This reveals that the increased activity of TNF- $\alpha$ and IL-6 in DH rats play a key role in the occurrence and development of $\mathrm{DH}$ neuropathic pain, and also shows that high expression of A20 protein can inhibit inflammation and ameliorate nerve root pain in DH rats.

A large number of studies have shown that apoptosis is related to the degeneration of the pathophysiological changes of intervertebral disc tissue $(23,25)$. Excessive apoptosis leads to a decrease in the activity of intervertebral disc cells, coupled with changes in the composition of the extracellular matrix, eventually leading to irreversible degenerative changes in the intervertebral disc. In this study, when the A20 protein was up-regulated in DH rats, the proportion of nucleus pulposus cell apoptosis was significantly reduced. The changes in apoptosis and inflammatory factors in each group of rats are consistent. Wang et al. (26) previously reported that the expression levels of IL-1, IL-4 and TNF- $\alpha$ contribute to the apoptosis of intervertebral disc cells. Therefore, inhibiting the expression of inflammatory factors can reduce the proportion of apoptosis.

$\mathrm{NF}-\kappa \mathrm{Bp} 65$ is the main factor that plays a role in the $\mathrm{NF}-\kappa \mathrm{B}$ pathway, which mainly promotes the release of inflammatory factors, is often activated in the inflammatory response, and increases the chronic inflammatory damage of the intestinal mucosal tissue (27). Activation of NF$\kappa B p 65$ promotes inflammation and hyperalgesia of adjuvant 
arthritis in rats (28). Current research shows that after up-regulating the expression of A20 protein in DH rats, the expression level of NF- $\mathrm{\kappa Pp} 65$ protein is significantly reduced. This indicates that $\mathrm{DH}$ rats up-regulated the expression of A2 0 protein to relieve the neuronal pain and inflammation in $\mathrm{DH}$ rats, which may be related to the inhibition of NF-кBp65 activity. In conclusion, the current research results show that swimming can effectively alleviate radiculopathy in DH rats, which may be related to the down-regulation of inflammatory factors, the inhibition of NF- $\mathrm{\kappa Bp} 65$ pathway activity in NP, and the inhibition of NP cell apoptosis. In conclusion, our experimental data show that up-regulating the expression level of A20 protein in DH rats can effectively alleviate the nerve root pain in $\mathrm{DH}$ rats. This may be related to the down-regulation of inflammatory factors, the inhibition of NF- $\mathrm{kBp} 65$ pathway activity in the nucleus pulposus tissue and the inhibition of nucleus pulposus cell apoptosis. This may become an effective molecular therapy for $\mathrm{DH}$ disease.

\section{Acknowledgments}

Funding: None.

\section{Footnote}

Reporting Checklist: The authors have completed the ARRIVE reporting checklist. Available at https://atm. amegroups.com/article/view/10.21037/atm-21-6499/rc

Data Sharing Statement: Available at https://atm.amegroups. com/article/view/10.21037/atm-21-6499/dss

Conflicts of Interest: All authors have completed the ICMJE uniform disclosure form (available at https://atm. amegroups.com/article/view/10.21037/atm-21-6499/coif). The authors have no conflicts of interest to declare.

Ethical Statement: The authors are accountable for all aspects of the work in ensuring that questions related to the accuracy or integrity of any part of the work are appropriately investigated and resolved. This study was approved by the ethics committee of the first hospital of Lanzhou University [approval No. (2020) No. 9-2], in compliance with The Principles of Human Experimental Technique, which is a national guideline for the care and use of animals to minimize the suffering of experimental animals.
Open Access Statement: This is an Open Access article distributed in accordance with the Creative Commons Attribution-NonCommercial-NoDerivs 4.0 International License (CC BY-NC-ND 4.0), which permits the noncommercial replication and distribution of the article with the strict proviso that no changes or edits are made and the original work is properly cited (including links to both the formal publication through the relevant DOI and the license). See: https://creativecommons.org/licenses/by-nc-nd/4.0/.

\section{References}

1. Krekoukias G, Gelalis ID, Xenakis T, et al. Spinal mobilization vs conventional physiotherapy in the management of chronic low back pain due to spinal disk degeneration: a randomized controlled trial. J Man Manip Ther 2017;25:66-73.

2. Karademir M, Eser O, Karavelioglu E. Adolescent lumbar disc herniation: Impact, diagnosis, and treatment. J Back Musculoskelet Rehabil 2017;30:347-52.

3. Cho HK, Kim SY, Choi MJ, et al. The Effect of GCSB5 a New Herbal Medicine on Changes in Pain Behavior and Neuroglial Activation in a Rat Model of Lumbar Disc Herniation. J Korean Neurosurg Soc 2016;59:98-105.

4. Balik MS, Kanat A, Erkut A, et al. Inequality in leg length is important for the understanding of the pathophysiology of lumbar disc herniation. J Craniovertebr Junction Spine 2016;7:87-90.

5. Gugliotta M, da Costa BR, Dabis E, et al. Surgical versus conservative treatment for lumbar disc herniation: a prospective cohort study. BMJ Open 2016;6:e012938.

6. Shepard N, Cho W. Recurrent Lumbar Disc Herniation: A Review. Global Spine J 2019;9:202-9.

7. Righesso O, Falavigna A, Avanzi O. Correlation between persistent neurological impairment and clinical outcome after microdiscectomy for treatment of lumbar disc herniation. Neurosurgery 2012;70:390-6; discussion 396-7.

8. Brötz D, Küker W, Maschke E, et al. A prospective trial of mechanical physiotherapy for lumbar disk prolapse. J Neurol 2003;250:746-9.

9. Zhang M, Peng LL, Wang Y, et al. Roles of A20 in autoimmune diseases. Immunol Res 2016;64:337-44.

10. Lee EG, Boone DL, Chai S, et al. Failure to regulate TNF-induced NF-kappaB and cell death responses in A20-deficient mice. Science 2000;289:2350-4.

11. Vereecke L, Beyaert R, van Loo G. The ubiquitinediting enzyme A20 (TNFAIP3) is a central regulator of 
immunopathology. Trends Immunol 2009;30:383-91.

12. Nocturne G, Boudaoud S, Miceli-Richard C, et al. Germline and somatic genetic variations of TNFAIP3 in lymphoma complicating primary Sjogren's syndrome. Blood 2013;122:4068-76.

13. Nocturne G, Mariette X. Sjögren Syndrome-associated lymphomas: an update on pathogenesis and management. Br J Haematol 2015;168:317-27.

14. Musone SL, Taylor KE, Lu TT, et al. Multiple polymorphisms in the TNFAIP3 region are independently associated with systemic lupus erythematosus. Nat Genet 2008;40:1062-4.

15. Musone SL, Taylor KE, Nititham J, et al. Sequencing of TNFAIP3 and association of variants with multiple autoimmune diseases. Genes Immun 2011;12:176-82.

16. Siracuse JJ, Fisher MD, da Silva CG, et al. A20-mediated modulation of inflammatory and immune responses in aortic allografts and development of transplant arteriosclerosis. Transplantation 2012;93:373-82.

17. Compagno M, Lim WK, Grunn A, et al. Mutations of multiple genes cause deregulation of NF-kappaB in diffuse large B-cell lymphoma. Nature 2009;459:717-21.

18. Honma K, Tsuzuki S, Nakagawa M, et al. TNFAIP3/ A20 functions as a novel tumor suppressor gene in several subtypes of non-Hodgkin lymphomas. Blood 2009; 114:2467-75.

19. Kato M, Sanada M, Kato I, et al. Frequent inactivation of A20 in B-cell lymphomas. Nature 2009;459:712-6.

20. Sisto M, Lisi S, Lofrumento DD, et al. A failure of TNFAIP3 negative regulation maintains sustained NF$\kappa \mathrm{B}$ activation in Sjögren's syndrome. Histochem Cell Biol 2011;135:615-25.

Cite this article as: Xie Z, Chen J, Xiao Z, Li Y, Yuan T, Li Y. TNFAIP3 alleviates pain in lumbar disc herniation rats by inhibiting the NF-кB pathway. Ann Transl Med 2022;10(2):80. doi: 10.21037/atm-21-6499
21. de Souza Grava AL, Ferrari LF, Defino HL. Cytokine inhibition and time-related influence of inflammatory stimuli on the hyperalgesia induced by the nucleus pulposus. Eur Spine J 2012;21:537-45.

22. Akgun B, Kaplan M, Arici L, et al. Low back pain and sciatica related with the premenstrual period in patients with lumbar disc herniation. Turk Neurosurg 2010;20:437-41.

23. Yan J, Zou K, Liu X, et al. Hyperexcitability and sensitization of sodium channels of dorsal root ganglion neurons in a rat model of lumber disc herniation. Eur Spine J 2016;25:177-85.

24. Hunter CA, Jones SA. Corrigendum: IL-6 as a keystone cytokine in health and disease. Nat Immunol 2017;18:1271.

25. Alini M, Eisenstein SM, Ito K, et al. Are animal models useful for studying human disc disorders/degeneration? Eur Spine J 2008;17:2-19.

26. Wang SL, Yu YL, Tang CL, et al. Effects of TGF-beta1 and IL-1beta on expression of ADAMTS enzymes and TIMP-3 in human intervertebral disc degeneration. Exp Ther Med 2013;6:1522-6.

27. Gan H, Ouyang Q, Chen Y, et al. Activation of nuclear factor-kappaB and effects of anti-inflammatory treatment thereon in intestinal mucosa of patients with ulcerative colitis. Zhonghua Yi Xue Za Zhi 2002;82:384-8.

28. Luo JG, Zhao XL, Xu WC, et al. Activation of spinal $\mathrm{NF}-\kappa \mathrm{B} / \mathrm{p} 65$ contributes to peripheral inflammation and hyperalgesia in rat adjuvant-induced arthritis. Arthritis Rheumatol 2014;66:896-906.

(English Language Editor: L. Huleatt) 